\title{
Institutional forms of industrial safety of the state
}

\section{Vladimir Klimuk}

Baranovichi State University

21 Voikov St., 225404, Baranovichi, Brest Region, Republic of Belarus

PhD, Associate Professor, Vice-Rector for Scientific Work

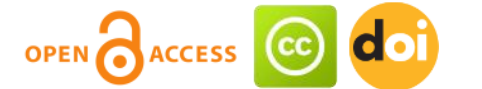

Article history:

Received: June 04, 2018

1st Revision: August 29,

2018

Accepted: October 26,

2018

\section{JEL classification: \\ L16 \\ L52 \\ 025}

DOI:

10.14254/jems.2018.3-2.8
Abstract: In this article, the state of Russian industry for 2014-2017 is analyzed. The system of basic indicators for assessing the level of industrial security based on the structure of national institutions is proposed. The role of the institutional environment in ensuring the industrial security of the country is presented and the principles for building an effective institutional platform are defined. The structure of the institutional mechanism for the development of the industry is proposed on the basis of a system of formbuilding components: regulatory, financial, social, foreign economic. As the basic methods are used the method of comparative analysis, the method of factor analysis, econometric modeling, matrix modeling. For each component, a number of quantitative indicators have been identified for the evaluation and analysis of the level of industrial development. Quantitative assessment allows us to present the qualitative side of the process of institutionalization in the relevant branch - industry. The basic algorithm of calculation is a process of three stages: the calculation of specific (share) indicators, intensive (tempo) and integral. The integrated indicator serves as a general indicator of the level of effectiveness of the institutional system of industrial security of the country. Based on the analysis of the development of the industry, a mechanism is proposed for the institutional functioning of the country's industry.

Keywords: institutional platform, industrial safety, industrial development, industrial development indicators for the assessment, sustainable development. 


\section{Introduction}

One of the leading branches of the country's economic system is industry, acting as the locomotive of security functioning. Progressive development based on intensification of production, innovation of industrial products, export expansion, quality of life, is conditioned by the level of influence of the system of institutions. According to the Prime Minister of the Russian Federation DA. Medvedev "... to achieve Russia's innovative development, it is necessary to carry out largescale rearmament and modernization of industry, stimulate, including through tax mechanisms, the replacement of obsolete equipment, transition to the principles of the best available technologies" (Institute of Innovation TUSUR, 2014). Academician S. Yu. Glazyev (2016), in an interview with the Russian radio, singled out two factors for the development of modern society: "scientific and technological progress (the main factor is innovation) and technological knowledge (the main factor is investment in human capital).

The formation of a favorable institutional environment in the industrial sector, the development of mechanisms for its operation, the construction of an industrial safety system is presented in the works of domestic researchers Andrushkiv, B., Vovk, Y., \& Pohajdak, O. (2011; 2012), Chernova O. A. (2009), Kushnarenko T. V. (2014), Matveyeva L. G. (2014), Volchik V. V. (2011), Erkeeva I. Kh. (2014) and others and foreign researchers Alvarez C. (2014), Belyi A. (2010), Andruseac G. (2015), Jerzmanowski M. and Walker J. E. (2017), Sabatini F. (2014) and others.

\section{Research methods}

Attention to the instrumentality of assessing the effectiveness of the institutional functioning of industry, modeling of the institutional platform as a basis for economic security of the state in these works is not properly given. Therefore, the resolution of this problem is the purpose of this research, which consists in developing a methodological apparatus for assessing, analyzing, modeling an institutional platform for industrial safety. The method of comparative analysis, matrix, econometric modeling is used as the methodological basis of the tool for assessing the effectiveness of industrial safety. The integral evaluation is based on complex calculations for individual components - production, economic, geopolitical.

Industrial safety is an integrated mechanism for creating conditions for sustainable industrial development of a country (region) in the integration of organizational, economic, political, environmental and other components in order to achieve a synergistic effect.

\section{Results and discussion}

\section{Calculation mechanism}

The industrial sector is a system-forming element of the socio-ecological and economic stability of the state (region). The dynamics of industrial development indicators affect the pace and level of changes in other sectoral sectors (Table 1).

\begin{tabular}{lllll}
\hline Table 1: Dynamics of industrial development indices for & $\mathbf{2 0 1 4 - 2 0 1 7}$ & \\
\hline Indicators & 2014 & 2015 & 2016 & 2017 \\
Share of industry in GDP,\% & 24,95 & 25,00 & 26,10 & 26,40 \\
Industrial productivity in industry, rub. & 2,97 & 2,92 & 2,93 & 2,93 \\
Salary return, RUB & 80,3 & 79,6 & 80,1 & 81,0 \\
Share of innovation costs in the volume of sales,\% & 2,32 & 2,75 & 2,77 & 2,79 \\
Investment return, RUB & 3,44 & 3,30 & 3,38 & 3,54 \\
\hline
\end{tabular}

Note: own development based on (Industry of Russia, 2015)

Economic growth is largely determined by the institutional basis of sustainable functioning, which forms the conditions for the country's progressive development. The component system of industrial safety formation is a set of regulatory, legal, credit and financial, social systems and the external sector (Figure 1). 
Figure 1: System interaction of the components of the industrial safety vector

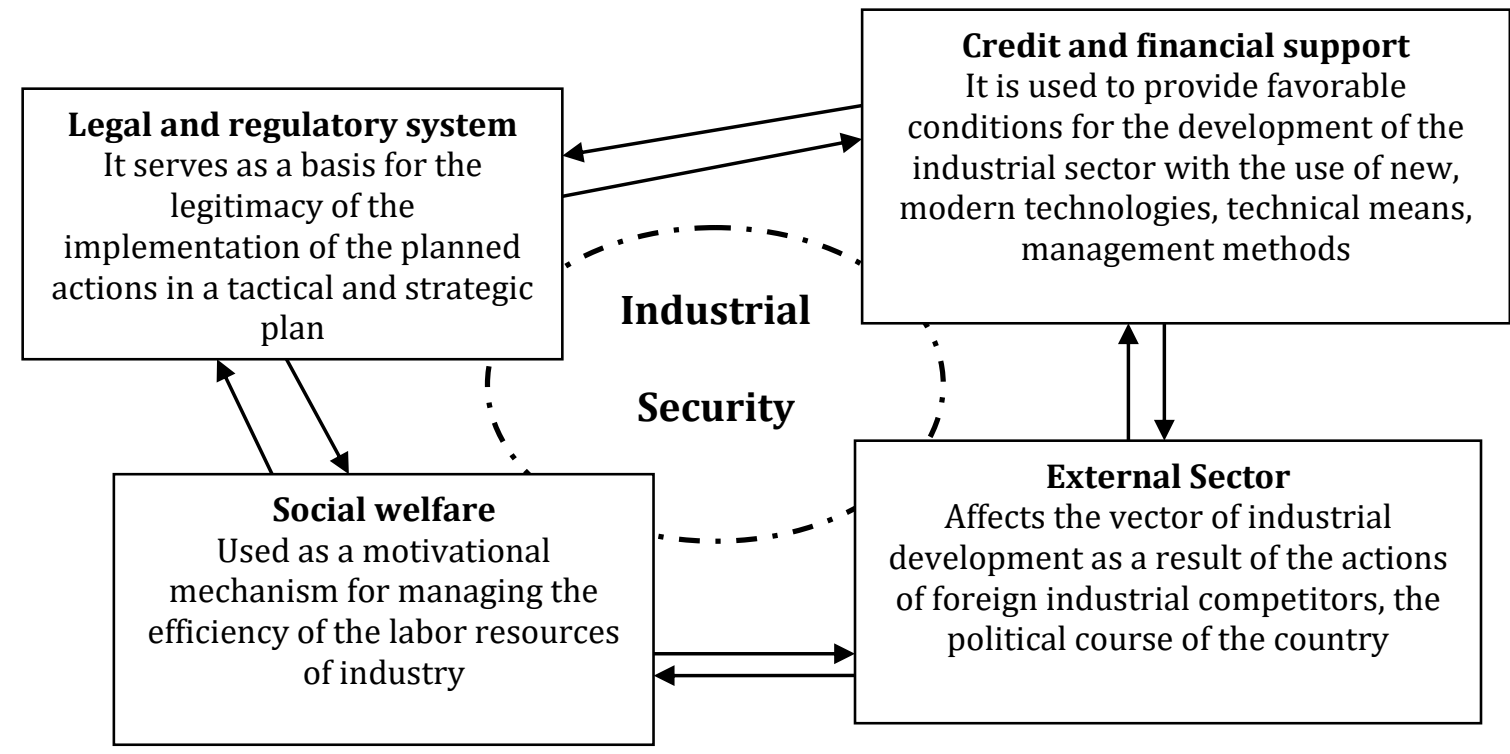

To assess the effectiveness of institutional support for industrial development of the country, it is necessary to present the differentiation of factors:

1. Production:

- the share of innovative products in total production;

- level of depreciation of fixed assets;

- material consumption of production.

2. Economic:

- share of investment in gross domestic product;

- The share of unprofitable organizations;

- the share of debt in the gross domestic product;

- profitability of sales;

- Dynamics of the main macroeconomic indicators.

3. Geopolitical:

- natural and climatic conditions;

- The political course.

In turn, the presented factors can be divided into exogenous (external influences) and endogenous (regulated within the country). The institutional platform used as the basic component of the country's functioning is based on the interconnection of individual blocks. To assess the effectiveness of the institutional platform, a set of quantitative indicators is proposed for the purpose of operational monitoring and making rational management decisions (Table 2).

\begin{tabular}{ll} 
Table 2: Block-indicator structure of the institutional platform for industrial development \\
\hline \multicolumn{1}{c}{ Block } & \multicolumn{1}{c}{ Monitoring indicators } \\
\hline Legal and regulatory system & - number of regulatory legal acts related to industry; \\
& - the share of goods from the sanctions list in the total volume of exports \\
& (imports); \\
& - number of priority directions in the sphere of industry in the Strategy of \\
& the country's social and economic development \\
& - number of industrial development programs (federal, regional, local); \\
& - the number of banking services under preferential terms of lending in \\
& industry; \\
Credit and financial support & - the share of loans to industry in the total amount of loan funds; \\
& - the share of subsidies in industry from the budget \\
& - level of income of the population (rate of change); \\
& - labour productivity; \\
& - share of non-industrial expenses in total revenue; \\
& - share of employed in the industrial sector \\
Social welfare & - average indices of prices for industrial products from abroad; \\
& - agreement on foreign economic cooperation; \\
& - the share of innovative products in total production; \\
& - the country's share in the global volume of exports and imports; \\
- commodity groups with identified and potential comparative advantages & of the country in the world
\end{tabular}


The goal of creating an institutional platform is to form a stable basis for institutional cooperation in the direction of ensuring industrial safety.

The effectiveness of the components of the institutional platform and the impact of its impact on industrial development depends on the mechanism of institutional functioning (Figure 3).

Figure 2: The mechanism of institutional functioning

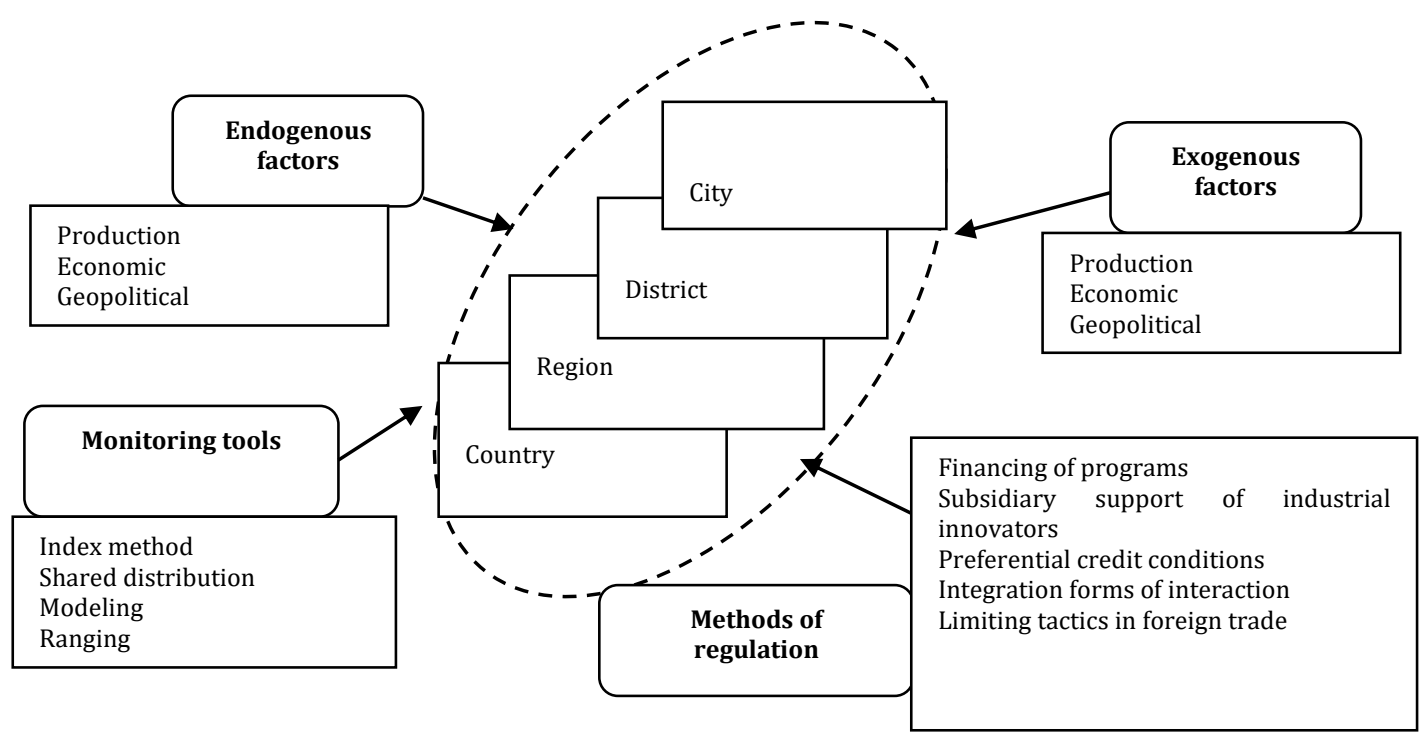

\section{Conclusion}

The proposed algorithm for assessing the effectiveness of the institutional mechanism for the functioning of the industrial sector of the economy will allow quantitatively to present the current state of development of the socioeconomic system of the country. Based on the consideration of several components, the evaluation side of the evaluation is detailed. Quantitative, but not qualitative, analysis allows us to present a valid concept of the planned strategy for strengthening the institutional mechanism. The basic set of indicators can be supplemented with new indicators to focus the analytical review on the basis of the targets for the object under study.

Accounting factor impact, applied assessment and analytical tools, a set of regulatory methods, the system of regulatory legal acts, credit and financial support ensure the quality of the created institutional base that manages the trends of industrial transformation and development based on system interaction. The institutional infrastructure of industry forms a vector of neoindustrialization, provides a diversified production system, and exports expansion in the system of economic security of the state.

\section{Acknowledgment}

\section{Funding}

The authors received no direct funding for this research.

\section{Citation information}

Klimuk, V. (2018). Institutional forms of industrial safety of the state. Economics, Management and Sustainability, 3(2), 107-111. doi:10.14254/jems.2018.3-2.8.

\section{References}

Álvarez, C., Urbano, D., \& Amorós, J. E. (2014). GEM research: achievements and challenges. Small Business Economics, 42(3), 445-465.

Andruseac, G. (2015). Economic security-new approaches in the context of globalization. CES Working Papers, 7(2), 232-240.

Andrushkiv, B. M., Vovk, Y. Y., Vovk, I. P. et al. (2012). Resursonomika: teoretychni ta prykladni aspekty [Resourcenomy: theoretical and applied aspects]. Ternohraf, Ternopil. 
Andrushkiv, B., Vovk, Y., \& Pohajdak, O. (2011). Crisis of relationship in general theory of crisis. Journal of European Economy, 10(2), 127-137.

Belyi, A. V., \& Overland, I. (2010). New narratives on Russian renewable energy policy. Revue de l'Energie, (594), 99-105.

Chernova, O. A. (2009). System-forming principles for the formation of a strategy for innovative development of the region. Bulletin of the Orenburg State University, 116(10), 46-51.

Glazyev, S. (2016). Problems of development of new technologies in Russia". The Russian radio. Retrieved April 13, 2016, from http://www.bourabai.kz/articles/glazev0.htm.

Industry of Russia. (2015). Statistical Bulletin. Moscow.

Institute of Innovation TUSUR. (2014). Dmitry Medvedev talked about the strategy of innovative development. Retrieved June 5, 2018, from http://2i.tusur.ru/?p=3050.

Jerzmanowski, M. (2017). Finance and sources of growth: evidence from the U.S. states, 22(1), 97122.

Kushnarenko, T. V. (2014). Theoretical and institutional basis of non-raw development of regional economies. TerraEconomicus, 12(2-3), 197-201.

Matveeva, L. G. (2014). Innovation potential of the industry of the South of Russia: a management tool for reducing regional asymmetry. Regional economy. South of Russia, 1, 42-54.

Matveyeva, L. G. (2016). Regional clusters of import substitution: Theory and modernity: Monograph.

Sabatini, F., Modena, F., \& Tortia, E. (2014). Do cooperative enterprises create social trust?. Small Business Economics, 42(3), 621-641.

Volchik, V. V. (2011). Globalization and the means of institutional economics in the study of institutional changes in the economy. The Economic Herald of Donbass, 26(4), 61-69.

Yerkeev, I. H. (2014). Economic security of the state as part of national economic security and state security. Black Holes in Russian Legislation, 2, 36-40.

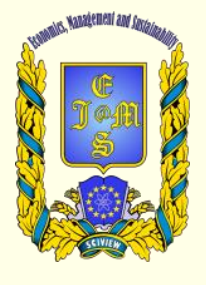

(c) 2016-2018, Economics, Management and Sustainability. All rights reserved.

This open access article is distributed under a Creative Commons Attribution (CC-BY) 4.0 license.

You are free to:

Share - copy and redistribute the material in any medium or format Adapt - remix, transform, and build upon the material for any purpose, even commercially.

The licensor cannot revoke these freedoms as long as you follow the license terms.

Under the following terms:

Attribution - You must give appropriate credit, provide a link to the license, and indicate if changes were made.

You may do so in any reasonable manner, but not in any way that suggests the licensor endorses you or your use.

No additional restrictions

You may not apply legal terms or technological measures that legally restrict others from doing anything the license permits.

Economics, Management and Sustainability (ISSN: 2520-6303) is published by Scientific Publishing House "CSR",

Poland, EU and Scientific Publishing House "SciView", Poland

Publishing with JEMS ensures:

- Immediate, universal access to your article on publication

- High visibility and discoverability via the JEMS website

- Rapid publication

- Guaranteed legacy preservation of your article

- Discounts and waivers for authors in developing regions

Submit your manuscript to a JEMS at http://jems.sciview.net or submit.jems@sciview.net

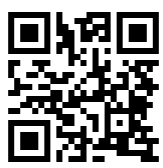

